\title{
SPRAWOZDANIE Z MIĘDZYNARODOWEJ KONFERENCJI NAUKOWEJ PT. DZIECI I SENIORZY W SIECI - ROLA I MIEJSCE ZAGROŻEŃ CYBERPRZESTRZENI W KONTEKŚCIE POLITYKI SPOŁECZNEJ KRAKÓW, 14-15 LISTOPADA 2018 ROKU
}

W dniach 14-15 listopada 2018 roku odbyła się w Instytucie Spraw Społecznych Uniwersytetu Pedagogicznego im. Komisji Edukacji Narodowej w Krakowie międzynarodowa konferencja naukowa pt. Dzieci i seniorzy $w$ sieci - rola $i$ miejsce zagrożeń cyberprzestrzeni w kontekście polityki spotecznej. Konferencja została zorganizowana przez Katedrę Profilaktyki Problemów Społecznych oraz Katedrę Gerontologii Społecznej Instytutu Spraw Społecznych Uniwersytetu Pedagogicznego im. Komisji Edukacji Narodowej w Krakowie.

Konferencja została zakwalifikowana do programu: „Krakowskie Konferencje Naukowe 2018" i dofinansowana z tego programu. Konferencja została objęta honorowymi patronatami: Ministra Rodziny, Pracy i Polityki Społecznej - Elżbiety Rafalskiej, Wojewody Małopolskiego - Jacka Krupy, Prezydenta Miasta Krakowa - Jacka Majchrowskiego, Jego Magnificencję Rektora Uniwersytetu Pedagogicznego w Krakowie - prof. dr. hab. Kazimierza Karolczaka, a także: Polskiego Towarzystwa Pedagogicznego, Polskiego Towarzystwa Polityki Społecznej oraz Fundacji Verum Alfa. Patronat medialny nad konferencją sprawowali TVP3 Kraków i Radio Kraków.

Przedmiotem szczególnego zainteresowania podczas konferencji była aktywność dzieci, młodzieży i seniorów w sieci oraz analiza zagrożeń cyberprzestrzeni w kontekście polityki społecznej. Refleksja nad rolą i miejscem zagrożeń cyberprze- 
strzeni była okazją do tego, by podjąć próbę naukowego oglądu i sformułowania wniosków, których aplikacja naukowo-badawcza i praktyczna umożliwi podjęcie odpowiednich działań profilaktycznych, edukacyjnych, a także tych o charakterze społecznym. Konferencja była także przygotowaniem do podejmowania odpowiednich działań w zakresie profilaktyki zagrożeń w zakresie cyberprzestrzeni oraz przyczyniła się do kształtowania świadomości nowego miejsca i roli tradycyjnych zagrożeń i uzależnień występujących w świecie rzeczywistym oraz ścisłego ich związku z nowymi niebezpieczeństwami mającymi miejsce $\mathrm{w}$ świecie wirtualnym.

Omawiane wydarzenie zgromadziło kilkudziesięciu uczestników, wśród których znaleźli się pracownicy naukowo-dydaktyczni z kilkunastu uczelni wyższych - polskich i zagranicznych, ale także pracownicy służb społecznych, nauczyciele, wychowawcy, przedstawiciele władz oświatowych, organów administracji publicznej oraz studenci.

Zgodnie z głównym hasłem konferencji organizatorzy zaproponowali następujące obszary tematyczne: służby społeczne wobec zagrożeń cyberprzestrzeni, dojrzałość w sieci - seniorzy wobec zagrożeń Internetu, patologie społeczne w przestrzeni cyfrowej, starzy i młodzi w Internecie - komunikacja międzypokoleniowa w cyberprzestrzeni, profilaktyka zagrożeń medialnych, bezpieczeństwo dzieci, młodzieży oraz osób starszych w cyberprzestrzeni, prawno-karne aspekty cyberprzestępczości i zagrożeń wirtualnych, metodyka pracy socjalnej w przestrzeni wirtualnej, warsztat pracy pracownika socjalnego w przestrzeni wirtualnej, sieciowy model wsparcia osób starszych wykluczonych cyfrowo, networking - praca socjalna w przestrzeni wirtualnej, seniorzy i młodzi w Internecie - społeczne konstruowanie generacji $\mathrm{w}$ świecie wirtualnym.

Komitet naukowy konferencji stanowiło kilkunastu profesorów m.in. prof. UP dr hab. Norbert G. Pikuła z Uniwersytetu Pedagogicznego w Krakowie, który był jednocześnie przewodniczącym Komitetu Naukowego Konferencji, prof. UP dr hab. Dariusz Adamczyk z Uniwersytetu Pedagogicznego w Krakowie, który był zastępcą przewodniczącego Komitetu Naukowego Konferencji, prof. dr hab. Joanna Madalińska-Michalak z Uniwersytetu Warszawskiego, ks. prof. dr hab. Andrzej Gretkowski z Wyższej Szkoły Pedagogicznej im. Janusza Korczaka w Warszawie, prof. UJK dr hab. Barbara Skałbania z Uniwersytetu Jana Kochanowskiego w Kielcach, prof. UJK dr hab. Sławomir Koziej z Uniwersytetu Jana Kochanowskiego w Kielcach, prof. PdDr Anna Żilova z uczelni: Katolicka Univerzita v Różomberku (Słowacja), doc. PhDr PaedDr Lýdia Lehoczká z uczelni: Uniwersita Konstantina v Nitre (Słowacja), prof. UP dr hab. Ireneusz M. Świtała z Uniwersytetu Pedagogicznego w Krakowie, prof. UJK dr hab. Tadeusz Sakowicz z Uniwersytetu Jana Kochanowskiego w Kielcach, prof. APS dr hab. Józef Bednarek z Akademii Pedagogiki Specjalnej w Warszawie, prof. UJ dr hab. Wojciech Kajtoch z Uniwersytetu Jagiellońskiego w Krakowie, prof. dr hab. Mariusz Jędrzejko z Centrum Profilak- 
tyki Społecznej w Milanówku, doc. dr Jirii Prokop z Charles University in Prague, prof. zw. dr hab. Walentyna Łozowiecka z Państwowej Akademii Nauk Pedagogicznych Ukrainy, prof. zw. dr hab. Bożena Muchacka z Uniwersytetu Pedagogicznego w Krakowie oraz prof. UAM dr hab. Jacek Pyżalski z Uniwersytetu im. Adama Mickiewicza w Poznaniu.

Komitet organizacyjny konferencji stanowili: dr Sylwester Bębas - przewodniczący Komitetu Organizacyjnego, dr Marek Banach - członek, dr Ewelina Zdebska - sekretarz oraz dr Józefa Matejek - sekretarz.

14 listopada 2018 roku w godzinach południowych nastąpiło uroczyste otwarcie konferencji przez Dziekana Wydziału Pedagogicznego Uniwersytetu Pedagogicznego w Krakowie - prof. UP dr hab. Ireneusza Świtałę oraz Dyrektora Instytutu Spraw Społecznych Uniwersytetu Pedagogicznego w Krakowie - prof. UP dr hab. Norberta G. Pikułę.

Następnie rozpoczęła się sesja plenarna, której moderatorami byli: prof. UP dr hab. Dariusz Adamczyk oraz dr Sylwester Bębas. Wykład wprowadzający w problematykę konferencji wygłosił prof. UAM dr hab. Jacek Pyżalski z Uniwersytetu im. Adama Mickiewicza w Poznaniu pt. „Co nowego o szansach i ryzykach mówią najnowsze badania EU Kids Online w Polsce?”. Niezmiernie interesujące i bogate w refleksje naukowe były wykłady podczas dalszych obrad, m.in. prof. UR dra hab. Jerzego Plisa z Uniwersytetu Rzeszowskiego pt. „Deficyt kontaktów interpersonalnych a cybertrybalizm”, prof. UTH dra hab. Mariusza Jędrzejki z Centrum Profilaktyki Społecznej w Milanówku pt. „Pobudzenie emocjonalne i zaniedbania edukacyjne jako konsekwencja "wchłonięcia» w sieć. Delegacje profilaktyczne”, ks. prof. KUL dra hab. Sylwestra Kasprzaka z Katolickiego Uniwersytetu Lubelskiego Jana Pawła II pt. „Kto jest odpowiedzialny za edukację do korzystania z Internetu - etyka internetowa”, prof. UP dra hab. Dariusza Adamczyka z Uniwersytetu Pedagogicznego w Krakowie pt. „Wychowanie w rodzinie do korzystania z Internetu”, dr Kai Zapędowskiej-Kling z Uniwersytetu Łódzkiego pt. „Polityka senioralna 2.0. - włączenie elementów interakcji i technologizacji do głównego nurtu polityki społecznej wobec osób starszych”, dr Katarzyny Wojtanowicz z Uniwersytetu Papieskiego Jana Pawła II w Krakowie pt. „Wykorzystanie cyberprzestrzeni do realizacji zadań pomocy społecznej”, czy dr Katarzyny Ziębakowskiej-Cecot z Uniwersytetu Technologiczno-Humanistycznego im. Kazimierza Pułaskiego w Radomiu pt. „Integracja polityki społecznej i oświatowej wobec zagrożeń bezpieczeństwa dzieci w świecie cyfrowym”.

Po zakończeniu obrad pierwszego dnia odbył się uroczysty obiad w pobliskiej restauracji „Santorini”, do której uczestnicy i zaproszeni goście udali się spacerem po krakowskiej dzielnicy Nowa Huta. Po obiedzie miało miejsce wieczorne zwiedzanie Krakowa, m.in. spacer po Kazimierzu.

W drugim dniu konferencji, 15 listopada 2018 roku, odbyła się sesja plenarna, której moderatorami byli: dr Marek Banach oraz dr Ewelina Zdebska. Była 
ona kontynuacją dyskusji z poprzedniego dnia. W tej części zostały wygłoszone następujące referaty: PhDr Ivo Syřršsta, dra Martina Beneša Bc. z uczelni: Pedagogická fakulta Univerzity Karlovy v Praze, pt. „Influence of social media on children behawior", dr Eweliny Zdebskiej z Uniwersytetu Pedagogicznego w Krakowie pt. „Cyberprzestrzeń jako przestrzeń spotkania rodzin dzieci niepełnosprawnych”, dr Katarzyny Jagielskiej z Uniwersytetu Pedagogicznego w Krakowie pt. „Aktywność wolnoczasowa emerytowanych nauczycieli”, dr Ewy Jasiuk z Uczelni Łazarskiego w Warszawie pt. „Działania Rady Europy w zwalczaniu cyberprzestępczości”, dr Sylwestra Bębasa z Uniwersytetu Pedagogicznego w Krakowie pt. „Patologie społeczne w przestrzeni cyfrowej”, dr Katarzyny Gucwy-Porębskiej z Uniwersytetu Pedagogicznego w Krakowie pt. „Destrukcja i autodestrukcja na sprzedaż. Patostream jako forma zagrożenia w sieci”, dr Dominiki Sozańskiej z Uniwersytetu Pedagogicznego w Krakowie pt. „Cyberprzestrzeń jako przestrzeń komunikacji dla osób z zaburzeniami odżywiania”, dr Wiolety Adamczyk-Bębas z Uniwersytetu Jana Kochanowskiego w Kielcach pt. „Profilaktyka cyberprzemocy wśród dzieci i młodzieży”, dr Józefy Matejek z Uniwersytetu Pedagogicznego w Krakowie pt. „Jestem online - Internet jako forma spędzania czasu wolnego”, mgra inż. Tomasza Woźniaka z Uniwersytetu Pedagogicznego w Krakowie pt. „Zagrożenia dzieci i młodzieży u schyłku drugiej dekady WEB 2.0”, mgr Elżbiety Mirewskiej z Uniwersytetu Pedagogicznego w Krakowie pt. „Internet jak źródło inspiracji w obszarze wybranych usług społecznych świadczonych w domach pomocy społecznej" oraz mgra Mirosława Mielczarka z Dolnośląskiej Szkoły Wyższej we Wrocławiu pt. „Świadomość młodzieży niedostosowanej społecznie wobec bezpiecznego korzystania z Internetu”. Drugi dzień obrad również zakończył się obiadem w restauracji „Santorini”.

Celem konferencji było: doskonalenie kwalifikacji w zakresie polityki społecznej oraz przekazanie wiedzy o możliwościach oraz zagrożeniach mediów interaktywnych i świata wirtualnego - w szczególności zagrożeń dla dzieci, młodzieży, osób starszych; analiza zagrożeń cyberprzestrzeni w kontekście polityki społecznej; dyskusja nad bezpieczeństwem dzieci i młodzieży oraz osób starszych w przestrzeni wirtualnej; wypracowanie obszarów wymagających pogłębienia naukowo-badawczego oraz zadań stojących przed edukacją, profilaktyką w zakresie zagrożeń cyberprzestrzeni.

Charakter i różnorodność podjętych przez referentów problemów oraz aktywny udział publiczności stały się przyczynkiem do ożywionej dyskusji. Konferencja bez wątpienia spełniła swój cel, stała się bowiem dla uczestników forum wymiany poglądów, umożliwiającym konfrontację swojej wiedzy i umiejętności z wiedzą innych. 